\title{
TESTING THE POSSIBILITY OF ZEOLITE APPLICATION ON POULTRY EXPOSED TO THE $\mathrm{G}_{2}$ AFLATOXIN EFFECT
}

\author{
Danka Maslić-Strižak ${ }^{1}$, Ljiljana Spalević ${ }^{1}$, Radmila Resanović ${ }^{2}$ \\ ${ }^{1}$ Scientific Veterinary Institute of Serbia, Belgrade, Vojvode Toze 14, \\ ${ }^{2}$ Faculty of Veterinary Medicine, Belgrade, Bulevar JNA 18 \\ maslicd@ikomline.net
}

\begin{abstract}
The presence of toxin producing fungi and mycotoxins in all types of raw materials used for animal feed production enables the appearance of aflatoxin residue in all of the tissues and organs, and especially in the meat, milk and eggs. In order to reduce the aflatoxin concentration in the food and its residue in the victuals of animal origin, various procedures can take place, among which is the application of sillicone mineral adsorbents. Since adsorbents have the possibility physically to link certain chemical components, and they are not themselves resorbed from the intestines, it is possible to prevent the toxin indigestion from the gastrointestinal tract. In the work, the possibility of the zeolite mineral clinoptilolite application with poultry exposed to the effect of $\mathrm{G}_{2}$ aflatoxin was tested. During the experiment on the broiler chickens, aflatoxin $\mathrm{G}_{2}$ intoxication was performed in the amount of $0.1 \mathrm{mg}$ per $1 \mathrm{~kg}$ of bodily mass during 21 days. After the experiment and the suffocation of animals, the presence of aflatoxin $\mathrm{G}_{2}$ residue in organs and tissues was tested in order to determine the protective effect of modified clinoptilolite. This work proved that aflatoxin given to the broilers in the amount of $1 \mathrm{mg}$ per $1 \mathrm{~kg}$ of bodily mass during 21 days does not cause disturbances in the state of health of the broiler chickens, but the production results were significantly reduced which were expressed in a statistically significant lower growth. It was also determined that the use of modified clinoptilolite through food prevents the deposition of aflatoxin $\mathrm{G}_{2}$ in the edible organs and tissues of chickens.
\end{abstract}

Key words: modified clinoptilolite; aflatoxin $\mathrm{G}_{2}$; residue; broiler chickens; growth; intoxication

\section{ИСПИТУВАњЕ НА МОЖНОСТА ОД ПРИМЕНА НА ЗЕОЛИТОТ КАЈ ЖИВИНА ИЗЛОЖЕНА ПОД ДЕЈСТВО НА G 2 АФЛАТОКСИНОТ}

\begin{abstract}
Присуството на токсин создаден од габи и микотоксините кај сите видови суровини кои се користат при производството на добиточна храна што овозможува појава на резидуи од афлатоксин во сите ткива и органи, а особено во месото, млекото и јајцата. Со цел да се намали концентрацијата на афлатоксинот во храната и неговите резидуи во продуктите од животинско потекло, може да се применат различни постапки, меѓу кои е и примената на силициумските минерални адсорбенси. Откако се утврди дека адсорбенсите имаат можност физички да поврзуваат одредени хемиски компоненти, а тие самите да не бидат ресорбирани од цревата, можно е да се спречи несварливоста на токсините од гастро-интестиналниот тракт. Во трудот беше испитувана можноста на примена на зеолитен минерал клиноптилолит кај живина изложена на дејството на $\mathrm{G}_{2}$ афлатоксинот. Во текот на експериментот со бројлерски пилиња, интоксикацијата на афлатоксинот $\mathrm{G}_{2}$ беше дадена во количина од $0,1 \mathrm{mg}$ на $1 \mathrm{~kg}$ телесна маса во текот на 21 дена. По експериментот и угушувањето на птиците, беше испитувано присуството на резидуите на афлатоксинот $\mathrm{G}_{2}$ во органите и ткивата со цел да се утврди заштитното влијание на модифицираниот клиноптилолит. Опитот покажа дека афлатоксинот даден кај бројлерите во количина од $1 \mathrm{mg}$ на 1кг телесна маса во текот на 21 дена, не предизвикува нарушувања на здравствената состојба кај бројлерските пилиња, но производствените резултати беа значајно опаднати што беше јасно изразено со статистички значаен помал пораст. Исто така, беше утврдено дека употребата на модифициран клиноптилолит даден преку храната го спречува таложењето на афлатоксинот $\mathrm{G}_{2}$ во јадливите органи и ткива кај пилињата.
\end{abstract}

Клучни зборови: модифициран клиноптилолит; афлатоксин $\mathrm{G}_{2}$; резидуи; бројлерски пилиња; пораст; интоксикација 


\section{INTRODUCTION}

It has been known for a long time that fungus can develop on certain cereals, oil plants, leguminous plants and other plant species in certain ecological conditions (Miličević D., 2009; Capriotti et al., 2010; Durate et al., 2010). Such contaminated plants, if used in food, can cause poisoning of people and animals. During the research, it was established that during the process of the fungi metabolism various metabolites develop, some of which are toxic for people and animals. The toxins that develop during the fungi metabolism and cause poisoning of people and animals are called mycotoxins. The disturbances of people's and animals' health caused by mycotoxins are called mycotoxicoses.

The number of known fungi grows every day, and with it the number of known toxin producing contaminants and the number of known mycotoxins. Today, there are over 3000 known mycotoxins. Even though the intoxications of people and animals with mycotoxins were noted as early as the Biblical days, a great number of laboratories approached the intensive research of mycotoxicoses and mycotoxins during the $1960 \mathrm{~s}$. The immediate cause for the intensification of dealing with these problems was the poisoning of 100000 turkeys in England. The poisoned turkeys were fed with peanut flour from which a mold was isolated and identified as Aspergillus Flavus ex Fries, and the isolated toxin was named aflatoxin.

Later on, many authors established that different molds of Aspergillus genus and Penicilium genus produced aflatoxin (Kulik and Holaday, 1966; Scott and associates 1967; Walbeek and associates 1968; Šutić and Banina, 1990; etc). The toxin production is a result of the interaction between a type of mold and the conditions in which it grows. Depending on the ground in which a culture is grown, the optimal temperature for the production of aflatoxins is lower than the one necessary for the growth of fungi (Davis and Dinner 1987; Austwick and Ayerst 1963; Schinder, 1967).

According to the molecular structure, the aflatoxins are classified among the heterocyclic derivatives of the bisfumarin-coumarin type. Until now, eighteen aflatoxins have been identified (S. Leeson and collaborators, 1995), which, according to the colour they fluoresce, are marked as aflatoxins B they fluorescence the color blue, and aflatoxins G, which fluorescence the color green.

If the animals consume food with aflatoxins, the aflatoxin residue can be found in every tissue and organ, and especially in the meat, milk and eggs (Rodricks and Stoloff, 1977 Miličević D., et al., 2011). Radović also discovered (1977) the aflatoxin residue in eggs of laying hens which were fed with food that contained aflatoxins, and in the edible parts of chickens.

It is necessary to reduce the quantity of aflatoxins in the food, in order to make the food usable, and by reducing the negative effect of aflatoxins on animals it is possible at the same time to prevent aflatoxicosis with people (Sinovec Z. J., Resanović R. D., 2005). In order to reduce the aflatoxin concentration, various procedures can be applied, from the application of additives in livestock feed, creating genetically more resistant animals, to the detoxification and detoxication of contaminated food through the use of physical and chemical methods.

One of the ways with which it is possible to prevent the harmful effects of aflatoxins is the application of silicone mineral adsorbents. Adsorbents can form physical links between certain chemical components, and, since they cannot be resorbed in the intestines, they prevent the ingestion of toxins from the gastrointestinal tract.

Natural zeolites show a high adsorbing capacity in the event of a low concentration of adsorbing material. The most widely used of all the zeolite minerals is clinoptilolite.

In veterinary medicine, zeolites can be used for ambience correction or as additives to livestock feed. Having used zeolites in the food for laying hens and broilers grown fat, it was possible to prevent the effects of the intoxication of livestock with T2 and aflatoxin (Palić and associates 1990; Resanović and associates, 1998; Maslić and associates 2010).

Goals of the work were:

- To follow the state of health of the chickens being grown fat, the clinical symptomatology of the intoxication and the dynamics of the dying of chickens after being orally intoxicated with aflatoxin $\mathrm{G}_{2}$ in the amount of $0.1 \mathrm{mg}$ per $1 \mathrm{~kg}$ of their bodily mass during 21 days.

- To analyze the presence of aflatoxin $\mathrm{G}_{2}$ residue in the organs and tissues of the broilers.

- To determine the protective effect that modified clinoptilolite has on the poultry exposed to the impact of the $\mathrm{G}_{2}$ aflatoxin

In order to obtain scientifically acceptable results, an experiment of subchronical intoxication 
with aflatoxin (21 days) was organized in vivo on the broiler chickens. During the experiment, the following parameters were followed and determined:

The state of health of the chickens in the experiment production results:

- bodily mass,

- growth (daily and total), and

- the mass of internal organs.

The presence of $\mathrm{AFG}_{2}$ residue in:

- the liver,

- kidneys,

- spleen,

- stomach (muscular and glandular), and

- the musculature (white and dark).

All of the results obtained were processed, shown and statistically analysed in order to draw certain conclusions.

For the subacute poisoning of the poultry, aflatoxin $G_{2}$ dissolved in ethanol was used, and then distilled water was added, so that 1 milliliter of the solution contained $0.1 \mathrm{mg}$ of aflatoxin. The dissolved aflatoxin was given to the chickens by a probe directly to the gullet in the amount of $1 \mathrm{mg}$ per $1 \mathrm{~kg}$ of bodily mass, that is, $1 \mathrm{ml}$ of the solution per $1 \mathrm{~kg}$ of bodily mass.

\section{MATERIAL AND METHODS}

Testing of the protective effect of clinoptilolite on poultry aflatoxicosis was performed in vivo.

\section{In vivo experiment}

For the testing of adsorbing capabilities of modified clinoptilolite in the situation of aflatoxin poisoning, 50 "Hibro" broiler chickens were used. All of them were 21 days old, both genders were present, and their origin was known. The animals were marked by a wing stamp. They were placed in cages of standard size for this type of poultry. The microclimate conditions were controlled during the experiment, and they were completely suitable for the technological norms for the provenance in question. Broilers were fed with a complete mixture for the feeding of chickens grown fat. The mixture had a standard raw material and chemical composition (Table 1), and it completely satisfied the broilers' needs (NRC, 1985; AEC, 1988).
Table 1

The chemical composition of the mixture used to feed the broilers

\begin{tabular}{lrlr}
\hline \hline $\begin{array}{l}\text { Raw material } \\
\text { composition }\end{array}$ & $\%$ & Chemical composition & \multicolumn{1}{c}{$\%$} \\
\hline Corn & 64.2 & Moisture & 11.30 \\
Soybeen seed & 28.5 & Ash & 5.89 \\
Fish flour, 65\% & 4.0 & Proteins & 19.26 \\
Meat and bone flour & 6.0 & Fat & 6.94 \\
Fat & 3.5 & Cellulose & 2.27 \\
Limestone flour & & Nitrogen-free & \\
& 0.5 & extraction components & 53.86 \\
Dicalcium phosphate & 1.0 & Calcium & 1.06 \\
Salt & 0.3 & Phosphorus & 0.81 \\
Vitamine-mineral & & ME,kJ/kg & 13.48 \\
additive & 1.0 & & 0.56 \\
Modified clinoptilolite & 0.5 & Lysine & 1.05 \\
\hline \hline
\end{tabular}

Before the beginning of the experiment, the food was tested for the presence of mycotoxins (aflatoxin, ochratoxin and trichotecenes) in a referential laboratory (Naučni institut za veterinarstvo Srbija Beograd - Scientific Veterinary Institute in Belgrade, Serbia). ROSA mycotoxin test (Rapid One Step Assay).

A seven-day quarantine before the start of the experiment was used for the broilers to adapt to the conditions of the ambience and to check their state of health. At the end of this period, a clinical testing of all the broilers took place in order to assess their general state of health.

\section{Aflatoxin $G_{2}$}

For the subacute intoxication of the poultry, pure crystal, analyzed aflatoxin $\mathrm{G}_{2}$ was used $\left(\mathrm{C}_{17} \mathrm{H}_{14} \mathrm{O}_{7}\right)$, (Aldrich Chemical Company and Inc.).

For the experiment, aflatoxin was dissolved in ethanol, and then distilled water was added, so that 1 milliliter of the solution contained $0.1 \mathrm{mg}$ of aflatoxins. The dissolved toxin was given to the chickens by a probe, directly to the gullet in the amount of $0.1 \mathrm{mg}$ per $1 \mathrm{~kg}$ of bodily weight that is $1 \mathrm{ml}$ of the solution per $1 \mathrm{~kg}$ of bodily mass.

\section{Modified Clinoptilolite}

Modified clinoptilolite is a mineral adsorbent gained by processing the zeolite tuff from around 
Zlatokop. The basic properties of this product are: particle size, cation exchange capacity, type of exchanged cations and chemical composition. (Djaković, 1998).

The stable suspension, which was possible to be given by a probe directly to the gullet, was gained by suspending the modified clinoptilolite (powder) in water. One milliliter of suspension contained $0.2 \mathrm{~g}$ of modified clinoptilolite. The modified clinoptilolite powder was added to the food by adding $250 \mathrm{~g}$ of zeolite to $50 \mathrm{~kg}$ of feed and mixed in a mixer.

\section{The Forming of the Experiment}

The animals experimented on were divided into five groups. Each group consisted of 10 chickens, and the groups were marked in this way:

The Control group of chickens (C) was given food with no modified clinoptilolite added;

The First group (I) of chickens was given food with $0.5 \%$ of modified clinoptilolite added;

The Second group (II) of chickens was given aflatoxin $\mathrm{G}_{2}$ orally by a probe directly to the gullet in the amount of $0.1 \mathrm{mg}$ per $1 \mathrm{~kg}$ of bodily mass;

The Third group (III) of chickens was given aflatoxin $G_{2}$ orally by a probe directly to the gullet in the amount of $0.1 \mathrm{mg}$ per $1 \mathrm{~kg}$ of bodily mass, and it was given food with $0.5 \%$ of modified clinoptilolite added;

The Fourth group (IV) of chickens was given the suspension of modified clinoptilolite orally by a probe directly to the gullet in the amount of 0.1 $\mathrm{mg}$ per $1 \mathrm{~kg}$ of bodily mass, and after that, they were given aflatoxin $\mathrm{G}_{2}$ orally by a probe directly to the gullet in the amount of $0.1 \mathrm{mg}$ per $1 \mathrm{~kg}$ of bodily mass.

\section{Following the clinical picture and the production results}

Each day at the same time intervals, after the application of aflatoxins, the broilers were permanently supervised for 30 minutes.

The animals were measured on an electronic scale with the accuracy of 10-2 g. Broilers were measured at the beginning of the experiment, and then regularly, each two days until the end of the experiment. The average bodily mass of chickens was calculated on the basis of the measurement results at the end of each phase, as well as at the beginning and the end of the entire experiment. Out of the difference in the bodily mass at the be- ginning and the end of each phase, the total growth was calculated, and on the basis of the duration of certain phases, as well as the experiment itself, the daily growth was calculated.

\section{Pathomorphological examinations}

Pathoanatomic examinations were performed after all the animals were suffocated using chloroform on the last day of the experiment.

After the macroscopic examination, the description, entry in the obduction protocol, measurement of the mass of the stomach and liver took place, the material examined (segments of the white muscle of the pectoral musculature, dark muscles of the rear extremities, the glandular and muscular stomach, liver, spleen and kidneys) was fixed in $10 \%$ formalin in its native state.

Parts of the mentioned organs were put in paraffin after being fixed and later dehydrated in a rising concentration of alcohol, and histological incisions (slices) $5 \mu \mathrm{m}$ thick were made using a "Reichert" sliding microtome. Out of every block, 4 to 6 slices were made, from various depth levels. The cuttings were then colored with haematoxylineosin (HE) according to Harris, which enabled the observation and research of the microscopic alterations in the material examined.

\section{Testing the tissues for residue}

For these tests the thin layered chromatography was used (according to J. Assoc. Offic. Anal. Chem. 64, 1981) to determine the presence of aflatoxins in the animal tissues (meat and organs).

\section{Statistical analysis of the results}

Because of the complexity of the research subject, several mathematic-statistical methods were used:

- the mean value - the measure of central tendency $\left(\mathrm{x}^{-}\right)$, the measures of variation - standard deviation (SD) and the standard error (SE);

-the coefficient of variation (CV) and the interval of variation (IV);

-variance analysis (group F test) and the Lsd test as the individual test.

Based on the arithmetic mean $\left(\mathrm{X}^{-}\right)$, the average bodily mass and growth were established according to the experimental groups. The variation measures have shown the variations of the bodily mass within one group (SD) and the percentage of variation between groups (CV). The variance 
analysis established a significant difference between the two observed experimental groups. All the tests were performed at the level difference of $5 \%$ and $1 \%$, and so the conclusions were given with a certain probability (95 and 99$)$. The results are shown in tables.

\section{RESULTS}

Following the state of health, a mild disturbance of broilers was noticed in the second, third and fourth group of chickens, immediately after the usage of aflatoxins. After this period, the behavior of broilers was normal in all the groups, and all of them seemed clinically healthy.

The average bodily mass of the broilers in certain groups was relatively equal at the beginning of the experiment, and the noted differences had no statistical significance $(p>0.05)$. During the experiment (Table 2), the differences in the average bodily mass at the end of the experiment were from $2.94 \mathrm{~g}$ (between group $\mathrm{C}$ and group I), $57.16 \mathrm{~g}$ (between group $\mathrm{C}$ and group III), $120.86 \mathrm{~g}$ (between group C and group IV) to 167.16 (between group $\mathrm{C}$ and group II).

Table 2

The broilers' bodily mass during the experiment

\begin{tabular}{|c|c|c|c|c|c|}
\hline \multirow[t]{2}{*}{ Measurement } & \multicolumn{5}{|c|}{ Group } \\
\hline & $\mathrm{C}$ & I & II & III & IV \\
\hline 1 & 848.40 & 851.76 & 873.60 & 826.40 & 829.50 \\
\hline 2 & 947.31 & 934.71 & 991.20 & 931.35 & 934.74 \\
\hline 3 & 1086.44 & 1085.34 & 1119.09 & 1069.74 & 1025.64 \\
\hline 4 & 1235.54 & 1219.89 & 1256.96 & 1192.56 & 1174.32 \\
\hline 5 & 1326.89 & 1323.74 & 1347.15 & 1293.08 & 1279.22 \\
\hline 6 & 1480.29 & 1458.14 & 1476.66 & 1443.19 & 1404.27 \\
\hline 7 & 1734.60 & 1700.48 & 1647.27 & 1693.23 & 1607.66 \\
\hline 8 & 1844.01 & 1831.41 & 1764.42 & 1816.29 & 1764.21 \\
\hline 9 & 1987.55 & 1999.79 & 1842.02 & 1927.70 & 1883.56 \\
\hline 10 & 2123.84 & 2120.90 & 1956.68 & 2066.73 & 2002.88 \\
\hline
\end{tabular}

The average growth of the broilers during the experiment is shown in Table 3 and it differs among individual groups during the experiment. The differences vary from significant to very sig- nificant $(\mathrm{p}<0.01)$. The most significant differences were found after the five day treatment with aflatoxin $G_{2}$, and then in the period between 15 , and 17 days from the start of the experiment. When the whole experiment is concerned the negative effect of $\mathrm{AFG}_{2}$ was expressed cumulatively in a statistically significant growth of the second group in comparison with the control group and the first group $(\mathrm{p}<0.01)$. The statistical significance was expressed in comparison with the third group which was protected by modified clinoptilolite added with the food, in comparison with the fourth group, where modified clinoptilolite was used in the form of suspension. The differences in the daily growth were not statistically significant. Even with the expressed numerical differences between the third and the first group, no statistically significant differences were found ( $p>0.05)$.

\section{Table 3}

Growth of the broilers during the experiment

\begin{tabular}{|c|c|c|c|c|c|}
\hline \multirow{2}{*}{$\begin{array}{c}\text { Experiment } \\
\text { day }\end{array}$} & \multicolumn{5}{|c|}{ Group } \\
\hline & Control & I & II & III & IV \\
\hline $1-3$ & 98.91 & 82.95 & 117.6 & 103.90 & 105.21 \\
\hline $3-5$ & $139.13^{x}$ & $150.63^{x}$ & $127.89^{\mathrm{a}}$ & $138.39^{x}$ & $90.93^{b, y}$ \\
\hline $5-7$ & 149.10 & 134.55 & 137.87 & 122.82 & 148.68 \\
\hline $7-9$ & 91.35 & 103.85 & 90.19 & 100.52 & 104.90 \\
\hline $9-11$ & 153.40 & 134.40 & 129.51 & 150.11 & 125.05 \\
\hline $11-13$ & 254.31 & 242.34 & 170.58 & 250.04 & 203.39 \\
\hline $13-15$ & 109.41 & $130.93^{x}$ & 117.18 & 123.06 & 156.55 \\
\hline $15-17$ & 143.54 & 163.38 & $77.60^{\mathrm{x}}$ & 111.41 & $119.39^{x}$ \\
\hline $17-19$ & $136.29^{\mathrm{a}}$ & 126.11 & $114.66^{\mathrm{b}}$ & 139.02 & 119.26 \\
\hline $1-19$ & 1275.44 & 1269.11 & $1083.08^{\mathrm{b}}$ & $1239.27^{\mathrm{a}}$ & $1173.36^{\mathrm{b}}$ \\
\hline
\end{tabular}

\section{Mass of internal organs}

Immediately after the suffocation of chickens, their livers and stomachs were weighed.

Table 4 shows the effect of modified clinoptilolite on the relative mass of the poisoned broilers' organs. A significant rise of the relative mass of the liver and stomach can be seen at the second group, the one that was given only AFG2. By giving modified clinoptilolite in food to the chickens in the third group, the relative mass of all the organs is reduced significantly. The adding of the modified clinoptilolite suspension had no effect on the relative mass of these organs. 


\section{Table 4}

Relative mass of liver and stomach (the measurements are expressed in \%)

\begin{tabular}{ccc}
\hline \hline Group & Liver & Stomach \\
\hline C & 2,929 & 1,857 \\
I & 2,659 & 1,792 \\
II & 3,286 & 2,054 \\
III & 2,990 & 1,868 \\
IV & 3,112 & 2,041 \\
\hline \hline
\end{tabular}

\section{$A F G_{2}$ residue in tissues and stomach}

In the liver of the control group and the first group of broilers, no presence of $\mathrm{AFG}_{2}$ residue was discovered (Table 5). In all the examined samples of the liver of the second group broilers, a presence of residue was discovered. The use of the modified clinoptilolite suspension significantly reduced the residue presence, and the use of modified clinoptilolite through food completely prevented the detection of $\mathrm{AFG}_{2}$ residue in the liver too.

Table 5

$A F G_{2}$ residue presence in the liver:

\begin{tabular}{cccccc}
\hline \hline Individual broiler & C & I & II & III & IV \\
\hline 1 & $\varnothing$ & $\varnothing$ & + & $\varnothing$ & + \\
2 & $\varnothing$ & $\varnothing$ & + & $\varnothing$ & $\varnothing$ \\
3 & $\varnothing$ & $\varnothing$ & + & $\varnothing$ & $\varnothing$ \\
4 & $\varnothing$ & $\varnothing$ & + & $\varnothing$ & $\varnothing$ \\
5 & $\varnothing$ & $\varnothing$ & + & $\varnothing$ & $\varnothing$ \\
6 & $\varnothing$ & $\varnothing$ & + & $\varnothing$ & $\varnothing$ \\
7 & $\varnothing$ & $\varnothing$ & + & $\varnothing$ & $\varnothing$ \\
8 & $\varnothing$ & $\varnothing$ & + & $\varnothing$ & + \\
9 & $\varnothing$ & $\varnothing$ & + & $\varnothing$ & $\varnothing$ \\
10 & $\varnothing$ & $\varnothing$ & + & $\varnothing$ & + \\
$\Sigma(\%)$ & 0 & 0 & 100 & 0 & 30 \\
\hline \hline
\end{tabular}

The presence of $\mathrm{AFG}_{2}$ residue in the broilers' kidneys was not discovered (Table 6). When the second group broilers were treated with aflatoxin, the presence of $\mathrm{AFG}_{2}$ residue was discovered in $90 \%$ of the tested kidney samples. The use of modified clinoptilolite suspension significantly reduced the presence of residue, and the use of modified clinoptilolite in food completely prevented the deposition of $\mathrm{AFG}_{2}$ and its residue in the kidneys.
Table 6

$A F G_{2}$ residue presence in the broilers' kidneys

\begin{tabular}{cccccc}
\hline \hline Individual broiler & $\mathrm{C}$ & $\mathrm{I}$ & $\mathrm{II}$ & $\mathrm{III}$ & $\mathrm{IV}$ \\
\hline 1 & $\varnothing$ & $\varnothing$ & + & $\varnothing$ & + \\
2 & $\varnothing$ & $\varnothing$ & + & $\varnothing$ & $\varnothing$ \\
3 & $\varnothing$ & $\varnothing$ & + & $\varnothing$ & $\varnothing$ \\
4 & $\varnothing$ & $\varnothing$ & + & $\varnothing$ & $\varnothing$ \\
5 & $\varnothing$ & $\varnothing$ & + & $\varnothing$ & $\varnothing$ \\
6 & $\varnothing$ & $\varnothing$ & + & $\varnothing$ & $\varnothing$ \\
7 & $\varnothing$ & $\varnothing$ & + & $\varnothing$ & $\varnothing$ \\
8 & $\varnothing$ & $\varnothing$ & + & $\varnothing$ & + \\
9 & $\varnothing$ & $\varnothing$ & + & $\varnothing$ & $\varnothing$ \\
10 & $\varnothing$ & $\varnothing$ & + & $\varnothing$ & + \\
$\Sigma(\%)$ & 0 & 0 & 100 & 0 & 30 \\
\hline \hline
\end{tabular}

The presence of $\mathrm{AFG}_{2}$ residue in the stomach of the broilers of the control group and group I was not discovered (Table 7). By treating the second group broilers with aflatoxin, the presence of $\mathrm{AFG}_{2}$ residue was discovered in $70 \%$ of the tested stomach samples. By using the mineral adsorbent suspension, the presence of residue was significantly reduced, and the use of modified clinoptilolite in the food completely prevented the deposition of $\mathrm{AFG}_{2}$ residue in the stomach.

Table 3

\begin{tabular}{|c|c|c|c|c|c|}
\hline Individual broilers & $\mathrm{C}$ & I & II & III & IV \\
\hline 1 & $\varnothing$ & $\varnothing$ & $\varnothing$ & $\varnothing$ & $\varnothing$ \\
\hline 2 & $\varnothing$ & $\varnothing$ & $\varnothing$ & $\varnothing$ & $\varnothing$ \\
\hline 3 & $\varnothing$ & $\varnothing$ & $\varnothing$ & $\varnothing$ & $\varnothing$ \\
\hline 4 & $\varnothing$ & $\varnothing$ & + & $\varnothing$ & $\varnothing$ \\
\hline 5 & $\varnothing$ & $\varnothing$ & + & $\varnothing$ & $\varnothing$ \\
\hline 6 & $\varnothing$ & $\varnothing$ & + & $\varnothing$ & $\varnothing$ \\
\hline 7 & $\varnothing$ & $\varnothing$ & + & $\varnothing$ & $\varnothing$ \\
\hline 8 & $\varnothing$ & $\varnothing$ & + & $\varnothing$ & + \\
\hline 9 & $\varnothing$ & $\varnothing$ & + & Ø & + \\
\hline 10 & $\varnothing$ & $\varnothing$ & + & $\varnothing$ & + \\
\hline$\sum(\%)$ & 0 & 0 & 70 & 0 & 30 \\
\hline
\end{tabular}

$\mathrm{AFG}_{2}$ residue presence in the spleen of the control group and second group broilers was not discovered (Table 8). By treating the second group broilers with aflatoxin, the presence of $\mathrm{AFG}_{2}$ residue was discovered in $80 \%$ of the tested spleen samples. The residue presence was significantly reduced by the use of the modified clinoptilolite suspension, and the use of modified clinoptilolite 
through food completely prevented the deposition of $\mathrm{AFG}_{2}$ and its residue in the spleen.

Table 8

$A F G_{2}$ residue presence in the broilers' spleen

\begin{tabular}{cccccc}
\hline Individual broilers & $\mathrm{C}$ & $\mathrm{I}$ & $\mathrm{II}$ & $\mathrm{III}$ & $\mathrm{IV}$ \\
\hline 1 & $\varnothing$ & $\varnothing$ & $\varnothing$ & $\varnothing$ & $\varnothing$ \\
2 & $\varnothing$ & $\varnothing$ & + & $\varnothing$ & $\varnothing$ \\
3 & $\varnothing$ & $\varnothing$ & + & $\varnothing$ & $\varnothing$ \\
4 & $\varnothing$ & $\varnothing$ & + & $\varnothing$ & $\varnothing$ \\
5 & $\varnothing$ & $\varnothing$ & + & $\varnothing$ & $\varnothing$ \\
6 & $\varnothing$ & $\varnothing$ & + & $\varnothing$ & $\varnothing$ \\
7 & $\varnothing$ & $\varnothing$ & + & $\varnothing$ & + \\
8 & $\varnothing$ & $\varnothing$ & $\varnothing$ & $\varnothing$ & + \\
9 & $\varnothing$ & $\varnothing$ & + & $\varnothing$ & $\varnothing$ \\
10 & $\varnothing$ & $\varnothing$ & + & $\varnothing$ & + \\
$\Sigma(\%)$ & 0 & 0 & 80 & 0 & 30 \\
\hline \hline
\end{tabular}

$\mathrm{AFG}_{2}$ residue in the muscles of broilers from the control group and the first group was not discovered (Table 9). By treating the second group broilers with aflatoxin, the presence of $\mathrm{AFG}_{2}$ residue was discovered in $70 \%$ of the tested muscle samples. The use of the modified clinoptilolite suspension completely prevented the deposition of AFG2 and its residue in the muscles.

Table 9

$A F G_{2}$ residue presence in the broilers' muscles

\begin{tabular}{cccccc}
\hline \hline Individual broilers & C & I & II & III & IV \\
\hline 1 & $\varnothing$ & $\varnothing$ & $\varnothing$ & $\varnothing$ & $\varnothing$ \\
2 & $\varnothing$ & $\varnothing$ & $\varnothing$ & $\varnothing$ & + \\
3 & $\varnothing$ & $\varnothing$ & + & $\varnothing$ & + \\
4 & $\varnothing$ & $\varnothing$ & + & $\varnothing$ & $\varnothing$ \\
5 & $\varnothing$ & $\varnothing$ & + & $\varnothing$ & $\varnothing$ \\
6 & $\varnothing$ & $\varnothing$ & + & $\varnothing$ & $\varnothing$ \\
7 & $\varnothing$ & $\varnothing$ & + & $\varnothing$ & $\varnothing$ \\
8 & $\varnothing$ & $\varnothing$ & + & $\varnothing$ & + \\
9 & $\varnothing$ & $\varnothing$ & + & $\varnothing$ & + \\
10 & $\varnothing$ & $\varnothing$ & $\varnothing$ & $\varnothing$ & $\varnothing$ \\
$\Sigma(\%)$ & 0 & 0 & 70 & 0 & 40 \\
\hline \hline
\end{tabular}

When summing up the results, it is obvious that the use of the mineral adsorbent - modified clinoptilolite in food completely prevented the AFG2 and its residue deposition in the examined tissues and organs, whereas the use of the modified clinoptilolite suspension significantly reduced the residue presence.

\section{DISCUSSION}

The disturbance after the aflatoxin application is thought to be a result of stress due to the capturing of broilers and the oral application of aflatoxin. The lack of the symptoms characteristic for aflatoxicosis can be explained by the dosage of the aflatoxin applied. The results we obtained are in accordance with the results give by Wyatt and his associates (1987), who believe that the display of the clinical picture of livestock aflatoxicosis primarily depends on the amount of toxins taken in, and on how long the organism has been exposed to the toxins. Sub chronic intoxication most of all affects the reduction of bodily mass and weaker conversion.

The negative effect of mycotoxins on the bodily mass and the daily growth of broilers we obtained during our work are in accordance with the data published by Osborn and associates in 1982; Giambrone and associates in 1985 and Huff and associates in 1992.

We conclude that the modified clinoptilolite had the protective effect in the gastrointestinal tract and that it prevented the adsorption of aflatoxin and its distribution through the organism, by comparing the reached bodily mass at the end of the fattening process among the broilers that were protected by modified clinoptilolite with the ones that were given only aflatoxin. Clinoptilolite added to the broilers' food, according to Harvey (1993), reduces the loss of bodily mass caused by aflatoxin for about $29 \%$ and the mortality for $41 \%$.

One of the indicators for the intoxication of the livestock with aflatoxin is the increase of the mass of the liver and stomach, because, due to the metabolism disturbance in the liver of chickens exposed to the effect of aflatoxins, hepatocellular necrosis takes place, hemorrhage and fat infiltration occur. After the end of the experiment, and the suffocation of animals, their liver and stomach were weighed. That mass was expressed as relative mass in relation to the weight of the individual broiler. The greatest relative mass of liver and stomach was noted in the group of broilers that was not protected by modified clinoptilolite.

Huff and Doerr (1981) and Kubena and associates (1989) have also reached the same results. The results we obtained are in accordance with the data from the biblography (Kubena and associates 1993; Harvey and associates 1993;) where the authors noted the increase of the relative mass of liver, kidneys, heart, stomach and the bursa of Fabricius among the broilers that were given aflatoxin 
in relation to the broilers who were protected by the adsorbent.

In the organs of broilers who were given both aflatoxin and modified clinoptilolite in their food, no presence of aflatoxin residue was found in any of the examined organs. The impossibility to detect aflatoxin in organs and tissue and especially in the liver as aflatoxin's target organ, leads to the conclusion that modified clinoptilolite, given with food provides an adequate protection from aflatoxicosis for the poultry. Given this way, modified clinoptilolite prevents aflatoxin resorption from the gastrointestinal tract and its distribution through blood to liver and other organs. Kubena and his associates (1993) used HSCAS instead of modified clinoptilolite in their work, and they received results similar to ours.

\section{CONCLUSIONS}

Aflatoxin given to broilers in the amount of $0.1 \mathrm{mg}$ per $1 \mathrm{~kg}$ of bodily mass, during 21 days, did not lead to any disturbance of the state of health of the chickens.

The presence of aflatoxin has a negative effect on the production results of the broilers grown fat. The negative effect of G2 aflatoxin is cumulatively expressed in a statistically significant lower growth. The use of modified clinoptilolite through food prevented the deposition of G2 aflatoxin and the appearance of the residue in the liver, kidneys, spleen, stomach and muscles.

\section{REFERENCES}

[1] Austwick P. K. C., Ayerest G. (1963). The toxicity of certain groundnut meals for poultry with special reference to their effect on ducklings and chickens. Vet. Record 73, 1215-1219.

[2] Capriotti A. L., Foglia P.,Gubbiotti R., Roccia C., Samperi R., Laganà A. (2010): Development and validation of a liqiud chromatography/atmospheric pressure photoionization-tendem mass spretrometric method for the analysis of mycotoxins subjected to commission regulation (EC) No. 1881/2006 In cereals. Journal of Chromatography A, 1217, 6044-6051.

[3] Davis N. D., Dienner V. L. (1987): Mycotoxins, In: Food and beverage Mycology, ed. L. R. Beuchat.

[4] Dumić M., Vukićević Olivera (1990): Prirodni zeoliti, upotreba u stočarstvu. ITNMS, Beograd.

[5] Duarte S. C., Pena A., Lino C. M. (2010): A review on ochratoxin A occurrence and effects. Food Microbioligy, 27, 187-198.

[6] Huff W. E., Doerr J. A. (1981): Synergism between aflatoxin and ochratoxin A in broiler chickens. Poult.Sci., 60, $555-559$
[7] Huff W. E., Kubena L. F., Harvey R. B., Corrier D. E., Mollenhauer H. H. (1986): Progression of aflatoxicosis in broiler chicken. Poult. Sci., 65. 1891-1899.

[8] Kubena L. F., Harvey R. B., Huff W. E., Orrier D. E., Phillips T. D., Rottinghaus G. E. (1989): Influence of ochratoxin A and T-2 singly and in combination on beoiler chickens. Poult. Sci., 68, 867-872.

[9] Kulik M. M., Holadey C. E. (1966): Aflatoxin: a metabolic product of several fungi, Mycopathology. Mycoll. Apll., 30: 137-140.

[10] Leeson, S., G., Summers D. J. (1995): Poultry metabolic disorders andmycotoxins, University Books, Ontario, Canada.

[11] Maslić Danka, Spalević Ljiljana, Resanović Radmila (2010): Uticaj mikotoksina na tov brojlerskih pilića, Savetovanje veterinara Republike Srpske, Teslić 2010.

[12] Miličević D., Nikšić M., Baltić Tatjana, Stefanović S., Jankovič S. (2009): Prisustvo plesni i mikotoksina u hrani za ishranu svinja - Značaj u proceni rizika. Tehnologija mesa, 50, 5-6, 281-270.

[13] Miličević D., Grubić Mira, Radičević Tatjana, Stefanović Srđan, Janković Saša, Vranić V. (2011): Prisustvo rezidua ohratoksina A u tkivima svinja i živine - Značaj u analizi rizika. Tehnologija mesa, 52, 2, $268-275$.

[14] Osborne D. J., Huff W. E., Hamilton P. B., Burtmeister H. R. (1982): Comparison of ohratoxin, aflatoxin and T-2 toxin for their effects on selected parameters related to digestion and evidence for specific metabolism of carotinoids in chickes. Poult. Sci., 61, 1646-1652.

[15] Ožegović L., Pepeljnjak S. (1995): Mikotoksikoze. Školska knjiga, Zagreb.

[16] Palić T., Vukićević O., Radmila Resannović, Rajić I. (1993): Primena prirodnih zeolitnih materija u proizvodnji živinskog mesa i jaja. Živinarstvo, XXII, 4-6, 52-54.

[17] Resanović Radmila, Palić T., Sinovec Snežana, Ivetić V., Sinovec Z. (2001): Prevention of aflatoxicoses in broilers using modified clinoptililite; XII Internatonal congress WVPA, 378.

[18] Radović V. (1997): Uticaj zeolita u ishrani kokoši nosilja rase Isabrown SSL na proizvodne rezultate i kvalitet jaja. Magistarska teza, Agronomski fakultet, Čačak.

[19] Rodriks J. V., Stoloff L. (1977): Foodproducing animals. In: Mycotoxins in Human and Animal Health (Ed.: Rodriks J. V., Hesseltine C. W., Mehlman M. A.), Pathtox Publishers Inc., USA, 67-69.

[20] Scott P. M., Walbeek W., Forgacs J. (1967): Formation of aflatoxins by A.o stianus, Apll. Mikrobiol., 15, 945-949.

[21] Schindler A. F., Palmer J. G., Eisenberg W. V. (1967): Aflatoxin production by $A$. Flavus as related to various temperatures. Apll. Microbiol., XV, 45-49.

[22] Sinovec Z. J., Resanović R. D. (2005): Mikotoksini u hrani za životinje - Rizik po zdravlje ljudi. Tehnologija mesa, 46, 1-2, 39-44.

[23] Walbeek W., Scott P. M., Thatcer F. S. (1968): Mycotoxins from food-borne fungi, Can. J. Microbiol.

[24] Šutic M., A. Banina (1990): Influence of aflatoxin B1 on gasproduction by lactic acid bacteria. J. Environ. Pathol. Toxicol. Oncol. 10, 149-153.

[25] Wyatt D. R., Marks H. L., Manning O. R. (1987): Selection for resistance to aflatoxin in chichkens. Poul. Sci., 66, 1901-1904. 